\title{
Factors Affecting Online Customer Satisfaction: The Sri Lankan Perspective
}

\author{
Piruni A. Deyalage ${ }^{1} \&$ Dushyantha Kulathunga ${ }^{1}$ \\ ${ }^{1}$ Faculty of Management Studies and Commerce, University of Sri Jayewardenepura, Gangodawila, Nugegoda, \\ Sri Lanka \\ Correspondence: Piruni A. Deyalage, Faculty of Management Studies and Commerce, University of Sri \\ Jayewardenepura, Gangodawila, Nugegoda, Sri Lanka. E-mail: piruni@sjp.ac.lk
}

Received: December 4, 2018

Accepted: January 16, 2019

Online Published: January 25, 2019

doi:10.5539/ijbm.v14n2p99

URL: https://doi.org/10.5539/ijbm.v14n2p99

\begin{abstract}
Customer satisfaction has been identified as an important phenomenon in relation to online shopping. The investigation of what cause customer satisfaction has become paramount for online businesses. Therefore, the purpose of this study was to identify the determinants of customer satisfaction in an online context. In this study, the authors proposed a conceptual model of customer satisfaction in the online context by identifying the key factors proposed by previous studies, and hypotheses were developed accordingly. The hypotheses were tested through multiple regression analysis, based on a sample of 150 online customers. The study found that customer service, website design and security perception were significantly associated with online customer satisfaction.
\end{abstract}

Keywords: Customer satisfaction, E- satisfaction, Online shopping, Sri Lanka

\section{Introduction}

The technological advancements and the Internet have resulted in proliferation of online shopping activities. This provides many opportunities for businesses to create and retain the relationships and interactions with the customers (Pappas, Pateli, Giannakos, \& Chrissikopoulos, 2014). Online shopping or electronic retailing has captured the attention of many retailers since it has been established as an alternative channel in combination with traditional offline retail channels (Rowley, cited in Harn, Khatibi, \& Ismail, 2006).

Even though the online mechanisms may provide easy to use and efficient methods of shopping (Momtaz, Islam, Ariffin, \& Karim, 2011), the customers may not opt for them if those mechanisms do not meet their expectations. Customers usually have a particular level of expectation in relation to a product or service. When expectations match with the performance, it is said that customers are satisfied, whereas the customers are dissatisfied when expectations are lower than the performance (Swan \& Combs, 1976). In general, a highly satisfied customer stays loyal to the company for a longer period of time (Williams \& Naumann, 2011). They tend to purchase more when the company introduces new products, spread positive word of mouth about the company and its products, offer new ideas to the company, provide less attention towards competing brands and less sensitive to the price (Kotler \& Keller, 2012). When the customer is satisfied with a particular online or offline store, there is a high tendency that he or she will shop again from that store.

Alternatively, customer dissatisfaction signals about the fact that service encountered was not matched with the expectations (Churchill, Jr, \& Surprenant, 1982). Customer dissatisfaction will lead to loss of customer loyalty, which in turn results in discontinuity of subsequent transactions and repeat purchases by that customer (Moriuchi \& Takahashi, 2016). Further, it has been identified that customer dissatisfaction arises as a result of service failure or feeling of service unfulfillment. Customer dissatisfaction has been identified as a significant predictor of customers' switching behavior (Bougie, Pieters, \& Zeelenberg, 2003)

When considering the above scenario, it is apparent that customer satisfaction is a very important factor which would determine the attraction of customers to an organization and its products and services. Further, it is apparent that customer satisfaction is important for retention of those customers with the organization in the long run. The concept of customer satisfaction and the resultant customer retention are critical for both online and offline businesses. Accordingly, the organizations would be interested in knowing the factors which can enhance the customer satisfaction. 
Thus, past researchers have looked at a variety of factors which would increase customer satisfaction. Accordingly, a research study conducted in Greek online shopping context has identified product information quality, user interface quality, service information quality, purchasing process convenience, security perception and product attractiveness as the significant determinants of customer satisfaction (Maditinos \& Theodoridis, 2010). Another study done by Trong, Khanh, and Gim (2014) has found website design, merchandise attributes, transaction capability, security/privacy, payment, delivery, customer service as the significant predictors of online customer satisfaction. Additionally, a recent study conducted by Tandon, Kiran, \& Sah (2017) has revealed website functionality and perceived usefulness as factors leading to customer satisfaction in an online shopping environment.

However, analysis of previous research indicated that the findings are inconsistent. For instance, Chen, Ling, Ying, and Meng (2012) found that website design is the most powerful independent variable which influences customer satisfaction in online shopping environment. In contrary to this study, Ranjbarian, Fathi, and Rezaei (2012) have identified that there is no significant association between website design and customer satisfaction. Further, Maditinos and Theodoridis (2010) identified that product information quality is highly related to the overall customer satisfaction. As oppose to this result, Evanschitzky, Iyer, Hesse, and Ahlert (2004) found that product information quality is not a significant determinant of online customer satisfaction.

The above discussion indicated that the findings related to customer satisfaction are not consistent and also, there are contradictory findings. Thus, it is apparent that there is no agreement among researchers about the significant factors influencing customer satisfaction. Therefore, the purpose of this study is to fill this research gap by identifying the significant factors affecting customer satisfaction in online context.

\section{Theoretical Background and Conceptual Model}

\subsection{Customer Satisfaction}

Customer satisfaction is identified as one of the most examined constructs in marketing literature. This plays a major role in competitive environment because of its ability to retain the existing customers and to introduce new customers. (Tandon et al., 2017). Kotler and Keller (2012, p.128) identified satisfaction as "a person's feeling of pleasure or disappointment which occurs as a result of the comparison between product or service performance and expectation". Another view point was provided by Oliver (2015, p.8), where he defined customer satisfaction as the "consumer's fulfillment response. It is a judgment related to a product/service feature, or the product or service has actually provided (or is providing) a pleasurable level of consumption-related fulfillment". Giese and Cote (2000) stated that customer satisfaction encompasses three basic components: a response (emotional or cognitive) pertaining to a particular focus (expectations, product, consumption experience, etc.) determined at a particular time (after consumption, after choice, based on accumulated experience, etc.).

However, in this research, customer satisfaction construct is mainly identified as the satisfaction of the customer in relation to his/her previous purchasing experience in online shopping. According to Flavián, Guinalíu, and Gurrea (2006) user satisfaction depends on the fulfillment of customer expectations. Therefore, it is important to undertake detailed analysis on the requirements of web site user.

\subsection{Factors Affecting Online Customer Satisfaction}

In order to achieve the objective of this study, first, the researchers had to determine the specific determinants of online customer satisfaction. This was not an easy task since different researchers had examined the area of online customer satisfaction differently, and of course using different constructs. Therefore, the researchers had to adopt an acceptable method for identifying the determinants of online customer satisfaction which can be used to develop a justifiable conceptual model. Consequently, the researchers went through thirty-one previous research articles which had examined online customer satisfaction. This extensive literature review enabled the researchers to uncover forty-five different determinants of online customer satisfaction, as identified in below Table 1. 
Table 1. Summary of determinants of online customer satisfaction

\begin{tabular}{|c|c|c|c|c|}
\hline \multirow{2}{*}{ No. } & \multirow{2}{*}{ Determinant } & \multirow{2}{*}{ Literature citation } & \multicolumn{2}{|c|}{ Citation count $(\mathrm{n}=31)$} \\
\hline & & & Frequency & Percentage \\
\hline 01 & Website design & $\begin{array}{l}\text { Szymanski and Hise (2000); Cho and Park (2001); Evanschitzky et al., (2004); } \\
\text { Kim(2005); Kim and Stoel (2004); H. Lin (2007); Anand (2007); Liu, He, } \\
\text { Gao, and Xie, (2008); Kim, Jin, and Swinney (2009);Chang and Chen (2009); } \\
\text { Alam and Yasin (2010), Maditinos and Theordoridis (2010); Al-Kasasbeh, } \\
\text { Dasgupta, and Al-Faouri, (2011); Eid (2011); Gelard and Negahdari (2011); } \\
\text { Chen et al. (2012); Guo, Ling, and Liu (2012); Dharmesti and Nugroho (2012); } \\
\text { Ranjbarian et al. (2012); Trong et al.(2014); Ting, Ariff, Zakuan, Sulaiman, \& } \\
\text { Saman (2016); Tandon et al.(2017) }\end{array}$ & 22 & $76 \%$ \\
\hline 02 & Security & $\begin{array}{l}\text { Szymanski and Hise (2000); Evanschitzky et al., (2004); Kim(2005); } \\
\text { Schaupp and Belanger (2005); H. Lin (2007); Anand (2007); Liu et al. (2008); } \\
\text { Zeng, Hu, Chen, and Yang (2009); Kim et.al.(2009); Chang and Chen (2009); } \\
\text { Maditinos and Theordoridis (2010); Eid (2011); Gelard and Negahdari (2011); } \\
\text { Guo et al. (2012); Dharmesti and Nugroho (2012); Ranjbarian et al. (2012); } \\
\text { Trong et al.(2014); Thilakarathne and Abeysekara (2016) }\end{array}$ & 18 & $62 \%$ \\
\hline 03 & Customer service & $\begin{array}{l}\text { Cho and Park (2001); Kim (2005); Anand (2007); Yang and Tsai (2007); Liu } \\
\text { et al. (2008); Zeng et al. (2009); Gelard and Negahdari (2011); C. Lin, Wu, } \\
\text { and Chang (2011); Ranjbarian et al. (2012); Guo et al. (2012); Silva and } \\
\text { Abeysekara (2012); Trong et al.(2014); Dharmesti and Nugroho (2012); Bellaj } \\
\text { (2013); Thilakarathne and Abeysekara (2016); Ting et al. (2016) }\end{array}$ & 16 & $55 \%$ \\
\hline 04 & $\begin{array}{l}\text { Product Information } \\
\text { Quality }\end{array}$ & $\begin{array}{l}\text { Szymanski and Hise (2000); Cho and Park (2001); Evanschitzky et al., } \\
\text { (2004); Kim (2005); H. Lin (2007); Liu et al.(2008); Maditinos and } \\
\text { Theordoridis (2010); Eid (2011); C. Lin et al. (2011) Gelard and Negahdari } \\
\text { (2011); Chen et al. (2012); Polites, Williams, Karahanna and Seligman (2012); } \\
\text { Guo et al. (2012); Dharmesti and Nugroho (2012); Khan, Liang, and Shahzad } \\
\text { (2015) }\end{array}$ & 15 & $52 \%$ \\
\hline 05 & $\begin{array}{l}\text { Purchasing process } \\
\text { convenience }\end{array}$ & $\begin{array}{l}\text { Szymanski and Hise (2000); Cho and Park (2001); Evanschitzky et al., } \\
\text { (2004) ; Kim (2005) ; Schaupp and Belanger (2005) ; Anand } \\
\text { (2007) ; Maditinos and Theordoridis (2010); Gelard and Negahdari (2011); } \\
\text { Ranjbarian et al. (2012); Silva and Abeysekara (2012); Khan et al. (2015); } \\
\text { Thilakarathne and Abeysekara (2016) }\end{array}$ & 12 & $41 \%$ \\
\hline 06 & Delivery & $\begin{array}{l}\text { Cho and Park (2001); Kim (2005); Schaupp and Belanger (2005); Liu et al. } \\
\text { (2008); Alam and Yasin (2010); C. Lin et al. (2011); Chen et al.(2012); Guo et } \\
\text { al.(2012); Dharmesti and Nugroho (2012); Trong et al. (2014) }\end{array}$ & 10 & $34 \%$ \\
\hline 07 & Response & $\begin{array}{l}\text { Kim and Stoel (2004); H. Lin (2007); Yang and Tsai (2007); Liu et al. } \\
\text { (2008); Kim et al. (2009); Dharmesti and Nugroho (2012; Ting et al. (2016) }\end{array}$ & 7 & $24 \%$ \\
\hline 08 & Payment & $\begin{array}{l}\text { Cho and Park (2001); Kim (2005); Liu et al. (2008); Guo et al. (2012); } \\
\text { Dharmesti and Nugroho (2012); Chen et al. (2012), Trong et al. (2014) }\end{array}$ & 7 & $24 \%$ \\
\hline 09 & Merchandising & $\begin{array}{l}\text { Cho and Park (2001); Schaupp and Belanger (2005); Anand (2007); Liu et al. } \\
\text { (2008); Ranjbarian et al. (2012); Trong et al. (2014) }\end{array}$ & 6 & $21 \%$ \\
\hline 10 & Price & $\begin{array}{l}\text { Cho and Park (2001); Kim (2005); C. Lin et al. (2011); Chen et al. (2012); } \\
\text { Khan et al. (2015); Thilakarathne and Abeysekara (2016) }\end{array}$ & 6 & $21 \%$ \\
\hline 11 & Privacy & $\begin{array}{l}\text { Schaupp and Belanger (2005); Yang and Tsai (2007); Eid (2011); Chen } \\
\text { et al. (2012); Ting et al. (2016) }\end{array}$ & 5 & $17 \%$ \\
\hline 12 & Fulfillment/reliability & $\begin{array}{l}\text { Yang and Tsai (2007); Kim et al. (2009); Zeng et al. (2009); Alam and Yasin } \\
\text { (2010); Ting et al. (2016) }\end{array}$ & 5 & $17 \%$ \\
\hline 13 & Transaction capability & $\begin{array}{l}\text { Kim and Stoel (2004); Liu et al. (2008); Dharmesti and Nugroho (2012); Trong } \\
\text { et. al. (2014); }\end{array}$ & 4 & $14 \%$ \\
\hline 14 & Product Offerings & $\begin{array}{l}\text { Szymanski and Hise (2000);Evanschitzky et al. (2004); Zeng et al. } \\
\text { (2009); Gelard and Negahdari (2011) }\end{array}$ & 4 & $14 \%$ \\
\hline 15 & Trust & Kim and Stoel (2004); H. Lin (2007); Polites et al. (2012); Chen et al.(2012) & 4 & $14 \%$ \\
\hline 16 & System Quality & $\begin{array}{l}\text { C. Lin et al. (2011); Polites et al. (2012); } \\
\text { Bellaj (2013) }\end{array}$ & 3 & $10 \%$ \\
\hline 17 & Perceived usability & Schaupp and Belanger (2005); Polites et al. (2012); Tandon et al. (2017) & 3 & $10 \%$ \\
\hline
\end{tabular}




\begin{tabular}{|c|c|c|c|c|}
\hline 18 & Product quality & Schaupp and Belanger (2005); C. Lin et al. (2011); Guo et al. (2012) & 3 & $10 \%$ \\
\hline 19 & Product variety & Alam and Yasin (2010); Dharmesti and Nugroho (2012); Guo et al. (2012) & 3 & $10 \%$ \\
\hline 20 & Ease of use & Cho and Park (2001); Zeng et al. (2009) & 2 & $7 \%$ \\
\hline 21 & Product attractiveness & Kim (2005); Maditinos and Theordoridis (2010) & 2 & $7 \%$ \\
\hline 22 & $\begin{array}{l}\text { Service information } \\
\text { quality }\end{array}$ & Maditinos and Theordoridis (2010); Trong et. al. (2014) & 2 & $7 \%$ \\
\hline 23 & Efficiency & Yang and Tsai (2007); Ting et al. (2016) & 2 & $7 \%$ \\
\hline 24 & Perceived usefulness & Tandon et al. (2017) & 1 & $3 \%$ \\
\hline 25 & Navigation & Al-Kasasbeh et al. (2011) & 1 & $3 \%$ \\
\hline 26 & Personalization & Al-Kasasbeh et al. (2011) & 1 & $3 \%$ \\
\hline 27 & Company & Gelard and Negahdari (2011) & 1 & $3 \%$ \\
\hline 28 & $\begin{array}{l}\text { Additional } \\
\text { information services }\end{array}$ & Cho and Park (2001) & 1 & $3 \%$ \\
\hline 29 & Interactivity & H. Lin (2007) & 1 & $3 \%$ \\
\hline 30 & Empathy & H. Lin (2007) & 1 & $3 \%$ \\
\hline 31 & Perceived value & Polites et al. (2012) & 1 & $3 \%$ \\
\hline 32 & User participation & Maditinos and Theordoridis (2010) & 1 & $3 \%$ \\
\hline 33 & Product customization & Schaupp and Belanger (2005) & 1 & $3 \%$ \\
\hline 34 & System Availability & Yang and Tsai (2007) & 1 & $3 \%$ \\
\hline 35 & Compensation & Yang and Tsai (2007) & 1 & $3 \%$ \\
\hline 36 & Time & Alam and Yasin (2010) & 1 & $3 \%$ \\
\hline 37 & Return policy & Khan et al. (2015) & 1 & $3 \%$ \\
\hline 38 & Web content quality & Bellaaj (2013) & 1 & $3 \%$ \\
\hline 39 & Promotional aspect & Silva and Abeysekara (2012) & 1 & $3 \%$ \\
\hline 40 & Technological aspect & Silva and Abeysekara (2012) & 1 & $3 \%$ \\
\hline 41 & Information fit to task & Kim and Stoel (2004) & 1 & $3 \%$ \\
\hline 42 & Entertainment & Kim and Stoel (2004) & 1 & $3 \%$ \\
\hline 43 & Product risk & Khan et al. (2015) & 1 & $3 \%$ \\
\hline 44 & Delivery risk & Khan et al. (2015) & 1 & $3 \%$ \\
\hline 45 & Financial risk & Khan et al. (2015) & 1 & $3 \%$ \\
\hline
\end{tabular}

\subsection{Conceptual Model}

For the purpose of this research, the researchers decided to select the most cited five determinants to develop the conceptual framework. Those five determinants have been used by more than $40 \%$ of the previous researchers, indicating the importance attributed to these determinants. Hence, the researchers can justify the selection of those five determinants for this study amongst the forty-five determinants identified in Table 1. The five determinants of online customer satisfaction chosen for the study were: Website design, Security perception, Customer service, Product information quality, and Purchasing process convenience. Based on the above justification the conceptual model (shown in Figure 1) depicting the relationships between five determinants and online customer satisfaction was developed.

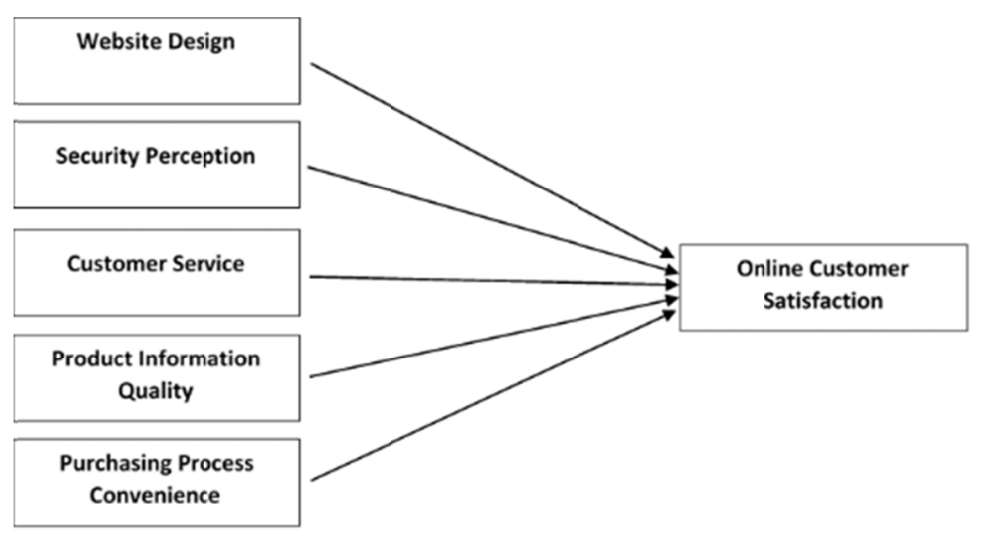

Figure 1. Conceptual model 


\subsection{Development of Hypotheses}

\subsubsection{Product Information Quality and Online Customer Satisfaction}

Product information quality refers to whether an online website provides sufficient, up to date, understandable and consistent information about its products (Maditinos \& Theordoridis, 2010). Park and Kim (2003) have identified that product information quality becomes crucial for customers when searching and purchasing products. The product information provided through an online store reduces the cost of information search and information processing (Park \& Kim, 2003). In general, information quality includes the characteristics of accuracy, timeliness, usefulness and completeness (Guo et al., 2012)

Many authors have empirically tested the relationship between product information quality and online customer satisfaction (Szymanski \& Hise, 2000; Cho \& Park, 2001; Kim, 2005; Lin, 2007; Liu et al., 2008; Maditinos \& Theordoridis, 2010; Eid, 2011; C. Lin et al., 2011 Gelard \& Negahdari, 2011; Polites et al., 2012; Guo et al., 2012; Dharmesti \& Nugroho, 2012; Evanschitzky et al., 2014; Khan et al., 2015).

Liu et al. (2008) and Maditinos and Theordoridis (2010) have identified product information quality as a strong predictor of online customer satisfaction. According to Liu et al. (2008), detailed product information need to be provided since the products are intangible in the online context. Therefore, customers highly rely on the information presented in the website during the information search and alternative evaluation stage. The quality information presented by the website assists customers in comparing products, making informed purchase decisions and enhancing transaction security (Liu \& Arnett, 2000; Park \& Kim, 2003; Lin, 2007). Khan et al. (2015) have also identified a positive association between product information quality and online customer satisfaction. Also, they have stated that the quality information shared by the website has a strong impact on customers since it helps consumers to overcome their fears, and then develop more favourable opinion towards the online store. Another study presented by Eid, 2011, identified that when the website provides accurate and reliable information, it will help to enhance customers' satisfaction and trust towards online website. Consequently, the following hypothesis is proposed.

$\mathbf{H}_{\mathbf{1}}$ : There is a positive effect of product information quality on online customer satisfaction

\subsubsection{Website Design and Online Customer Satisfaction}

Web site design describes the appeal that user interface design presents to customers (Kim \& Lee, 2002). According to Szymanski and Hise (2000) the ambience associated with the website and how it functions play a significant role in determining whether customers are satisfied with the website or not. The existing literature have further argued that user friendly design is an important factor which ensures success of the website (Chen et al., 2012). Shopping is perceived to be more pleasurable and satisfying by the customers when the website is fast, unclutter and easy to navigate (Pastrick, 1997; Szymanski \& Hise, 2000). According to Dharmesti and Nugroho (2012) good website design requires neat screen appearance, clear information path and quick information loading which will make online shopping more enjoyable to the customers and may affect customer satisfaction. It was further identified that, various website design factors such as navigation and graphic design have an effect on service quality which in turn affects online customer satisfaction (Kim, 2009).

The effect of website design on customer satisfaction has been studied extensively. Kim (2005) (as cited in Maditinos \& Theordoridis, 2010) found that the website design is a significant determinant of online customer satisfaction. Liu et al., (2008) have also identified a positive relationship between website design and online satisfaction and their findings are consistent with the findings of Szymanski and Hise (2000); Chang and Chen (2009) and Eid (2011). The study of Liu et al. (2008) further indicates that putting much effort on website design is important since the customers' first impression on website is derived through page design, layout and colour match. Also a well-designed website helps to attract the customers and increase the possibility of purchase by improving the satisfaction level of customers. Al- Kasabeh et al. (2011), Gelard and Negahdari (2011) and Evanschitzky et al. (2014) have also empirically tested this effect and identified the website design as a strong predictor of customer satisfaction. Consequently, the following hypothesis is proposed.

$\mathbf{H}_{2}$ : There is a positive effect of website design on online customer satisfaction

\subsubsection{Purchasing Process Convenience and Online Customer Satisfaction}

This construct highlights the easiness and convenience associated when purchasing a product via an online shopping site. It is vital for an online store to offer a simplified, easy, and quick purchasing process for the customer (Maditinos \& Theordoridis, 2010). Their study has revealed that when the process is more convenient for the customers, higher the satisfaction level they have towards the online store. 
This relationship has been further confirmed by the studies done by Szymanski and Hise (2000); Cho and Park (2001); Kim (2005); Schaupp and Belanger (2005); Anand (2007); Maditinos and Theordoridis (2010); Gelard and Negahdari (2011); Silva and Abeysekara (2012); Evanschitzky et al. (2014); and Khan et al. (2015). In Sri Lankan context also Silva and Abeysekara (2012) have found out that the convenience that customers experience during their Internet banking activities have strong, positive influence on customer satisfaction. Consequently, the following hypothesis is proposed.

$\mathbf{H}_{3}$ : There is a positive effect of purchasing process convenience on online customer satisfaction

\subsubsection{Security Perception and Online Customer Satisfaction}

Security refers to safety, personal information management and payment security (Maditinos \& Theordoridis, 2010). It is identified as one of the important factors considered by online customers. Therefore, the online retailers need to give special attention to create a safe online shopping environment (Liu et al, 2008). Security credential provided by the online store, privacy policy and trust are several parameters of online security (Maditinos \& Theordoridis, 2010). According to Park and Kim (2003), before revealing their personal data and purchasing from an online store customers expect detailed information on how their personal and transaction data are secured.

The lack of perceived security is identified as one of the major reasons why the potential customers resist to shop online. Mainly, due to the risk involved in transmitting sensitive information such as credit card information, customers are reluctant to engage with online shopping activities. Customers who provide this information believe that their security can be compromised due to online activities. Therefore, much concern is given on the security of their transactions (Chang \& Chen, 2009). When the e-retailers incorporate more security features to their website it results in high level of customer satisfaction (Maditinos \& Theordoridis, 2010).

Several studies have attempted to investigate the effect of security perception on customer satisfaction and majority of researchers have established that there is a significant and positive association exist between security perception and online customer satisfaction (Szymanski \& Hise,2000; Kim,2005; Schaupp \& Belanger ,2005; H. Lin ,2007; Anand,2007; Liu et al.,2008;Kim et.al.,2009; Chang \& Chen 2009 ; Maditinos \& Theordoridis,2010; Gelard \& Negahdari 2011; Guo et al.,2012; Dharmesti \& Nugroho,2012 ; Ranjbarian,2012 ; Trong et al., 2014; Evanschitzky et al.,2014). A study done in the Sri Lankan context has also found that there is a signifincant and positive effect of security on customer satisfaction (Thilakarathne \& Abeysekara, 2015). Consequently, the following hypothesis is proposed.

$\mathbf{H}_{4}$ : There is a positive effect of security perception on online customer satisfaction

\subsubsection{Customer Service and Online Customer Satisfaction}

In general, customer service can be identified as willingness of personnel to help in solving problems and provide prompt responses to enquiries (Chang \& Chen, 2009). Several researches have been undertaken to examine the effect of customer service on customer satisfaction. For instance, Ranjbarian et al. (2012); Trong et al. (2014); Guo et al. (2012); Dharmesti and Nugroho (2012) have tested customer service as one of the determinants of online customer satisfaction and revealed that customer service has a significant and positive influence on online customer satisfaction. In Sri Lanka also, customer service was tested by Thilakarathne and Abeysekara (2015) using the variable "customer care" and Silva and Abeysekara (2012) using the variable "bank staff assistance". Their findings also indicated that a positive relationship exists between customer service and customer satisfaction.

According to Liu et al. (2008) customer service play a significant role in online customer satisfaction. Prompt responses need to be provided in order to address customer concerns and inquiries. The customer representatives should be able to assist the customer in solving problems as soon as they occur. This is important because the ignorance of customer inquiries may cause customer dissatisfaction. The customers seem to be highly satisfied when quality of customer service is high (Dharmesti \& Nugroho, 2012). Since the customer may need additional information or services from the organization, it is important to provide a method of contacting the customers to make complaints or ask information relevant to products or online store. Thilakarathne and Abeysekara (2016) have stated that customer service is a hygiene factor which affect customer satisfaction. Therefore, the absence of quality customer service can have adverse impact on customer satisfaction. Consequently, the following hypothesis is proposed.

$\mathbf{H}_{5}$ : There is a positive effect of customer service on online customer satisfaction 


\section{Research Method}

\subsection{Sample}

The sample procedure used was convenient sampling since it is the best way to collect information quickly and efficiently (Momtaz et al., 2011). The study sample comprised of 230 MBA students of University of Sri Jayewardenepura. This sample was selected for the study due to several reasons. Firstly, students are among the most active online buyers. And they were considered to be suitable sample for online shopping research due to their online and actual purchasing experiences, technological advances and innovativeness (Yoo \& Donthu, 2001). Secondly, online consumers are recognized as younger and highly educated than conventional consumers, making students more related to the online consumer population (McKnight, Choudhury, \& Kacmar, 2002). Finally, they have the opportunity to use the Internet for communication and commercial transactions (Walczuch \& Lundgren, 2004)

\subsection{Data Collection}

Data collection of the study was done by personally distributing the questionnaires to the MBA students who were present in the classes. Consequently, 178 responses could be collected in two attempts spanning two weeks. Evaluation of the questionnaires revealed that there were 21 respondents who lacked any online purchasing experience. Due to the nature of the research, those responses had to be eliminated. Further, there were 7 incomplete responses and they too were eliminated from further analysis. Consequently, the researchers were left with a total of 150 questionnaires for analysis of this study.

\subsection{Instrument Development}

The questionnaire consisted of two sections. The first section covered demographic information of respondents such as gender, age, income, online shopping experience and frequency of online shopping activities. The second section included the measurements to measure the six constructs identified in the conceptual model. In order to measure the constructs, pretested items were adopted from previous literature. The questionnaire was developed using multiple item method and each item was measured based on a five-point Likert scale ranging from "strongly disagree" to "strongly agree" (refer appendix for questionnaire). Table 2 illustrates the adaptation of measurements from different researchers.

Table 1. Adoption of Questionnaire Measurements

\begin{tabular}{ll}
\hline \multicolumn{1}{c}{ Construct } & \multicolumn{1}{c}{ Adapted from } \\
\hline Website design & Park and Kim (2003); Lee and Lin (2005);Liu et al. (2008); Maditinos and Theodoridis (2010) \\
$\begin{array}{l}\text { Security perception } \\
\text { Customer service }\end{array}$ & Liu et al. (2008); Chang et al. (2009);Wang, Tang, \& Tang, (2001); Jaing and Rosebloom (2015) \\
Product information quality & Cho and Park (2001); Park and Kim (2003); Kim (2005); Liu et al. (2008); Maditinos and Theodoridis \\
& (2010) \\
Purchasing process & Park and Kim (2003);Kim (2005); Maditinos and Theodoridis (2010) \\
convenience & \\
Customer satisfaction & Liu et al. (2008); Casalo, Flavian, and Guinaliu, (2008); Tandon et al. (2017) \\
\hline
\end{tabular}

\subsection{Respondents' Profile}

As presented in Table 3, analysis of respondents' demographic characteristics indicated a higher percentage of female respondents $(65.1 \%)$ compared to male respondents $(34.9 \%)$. Also, majority of the respondents $(62 \%)$ were from the age group of 18 - 30 years, indicating the consistence of younger respondents in the sample. In terms of highest education qualifications, 95 respondents $(63.3 \%)$ had undergraduate degrees whereas 42 respondents (28\%) had postgraduate degrees. Besides that, a large number of respondents (42\%) earn more the Rs. 100,000 as the monthly income, which is fairly above the average salary of employees in Sri Lanka. Seventy-seven respondents $(51.3 \%)$ have shopped online less than 5 times during the last year, indicating that their frequency of online shopping is somewhat lower. 
Table 2. Demographic profile of sample

\begin{tabular}{llcc}
\hline Measures & Items & Frequency & Valid \% \\
\hline Gender & Male & 52 & 34.9 \\
& Female & 97 & 65.1 \\
Age & Missing & 1 & \\
& $18-30$ & 93 & 62.0 \\
Highest Education Qualification & $31-45$ & 56 & 37.3 \\
& Above 45 & 1 & 0.7 \\
& Diploma & 1 & 0.7 \\
Monthly Income & Professional Qualification & 12 & 8.0 \\
& Undergraduate Degree & 95 & 63.3 \\
& Postgraduate degree & 42 & 28.0 \\
& Less than Rs.50, 000 & 37 & 25.3 \\
Frequency of online shopping during last year & Rs.50, 000 - Rs.100, 000 & 47 & 32.2 \\
& More than Rs.100,000 & 62 & 42.5 \\
& Missing & 4 & \\
& 5-20 times & 77 & 51.3 \\
& More than 20 times & 54 & 36.0 \\
\hline
\end{tabular}

\section{Data Analysis and Findings}

The initial tests were performed in order to test multivariate assumptions. Normality was tested using Skewness and Kurtosis tests. Results indicated that all the values lie between -2 and +2 satisfying normal distribution of data set (George \& Mallery, 2016). Linearity was tested using scatter plot which depicted that linear relationship exist between each of independent variable and dependent variable. Homoscedasticity was also found to be satisfied based on the residual plot (Hair, Black, Babin, \& Anderson, 2014). Finally, multicollinearity was tested using correlation matrix which generated correlation coefficients below 0.9 . This indicated that there is no considerable level of multicollinearity among variables in the study (Saunders, Lewis, \& Thornhill, 2009). Since all the multivariate assumptions were satisfied analysis, the researchers could proceed with inferential statistics.

\subsection{Validity and Reliability}

Validity focuses on identifying, extent to which the research concept is correctly represented by the measures (Hair et al., 2014). This was tested using content validity and construct validity. Content validity is "assessment of the correspondence of the variables to be included in a summated scale and its conceptual definition" (Hair et al., 2014, pp.123). Constructs used for this study were developed based on established literature (Table 2). Also, the indicators of the independent and dependent variables were operationalized based on existing literature. Thus, this process ensured a higher level of content validity.

Construct validity was measured by utilizing convergent validity and discriminant validity. In order to suggest adequate convergent validity, average variance extracted (AVE) should be equal or greater than 0.5 (Hair et al., 2014). As per Table 4, AVE of all constructs lies above 0.5 indicating convergent validity of them. In order to determine discriminant validity, square root of AVE of each construct was compared to the squared correlations of other constructs. From Table 5, it is evident that square root of AVE value (bold values shown along the diagonal) of each construct is greater than the squared correlations of this construct to any other construct. Hence, the discriminant validity is established (Hair et al., 2014).

Reliability is "an assessment of the degree of consistency between multiple measurements of a variable" (Hair et al., 2014, pp123). The Cronbach's alpha was used to measure reliability of the measures. As per Hair et al. (2014) the value of Cronbach's alpha coefficient of 0.7 was taken as the threshold level in order to ensure the stability and consistency of the instruments. According to Table 4, the Cronbach's alpha value of all six constructs were above 0.7 . Hence, the reliability of the construct is established. 
Table 3. Summary of convergent validity and reliability results

\begin{tabular}{lccc}
\hline \multicolumn{1}{c}{ Construct } & No. of Items & AVE & Cronbach's Alpha \\
\hline Product information quality & 5 & 0.666 & 0.871 \\
Website deign & 6 & 0.657 & 0.894 \\
Purchasing process convenience & 3 & 0.750 & 0.833 \\
Security perception & 4 & 0.767 & 0.899 \\
Customer service & 5 & 0.654 & 0.864 \\
Customer satisfaction & 6 & 0.746 & 0.930 \\
\hline
\end{tabular}

Table 4. Discriminant validity results

\begin{tabular}{lcccccr}
\hline & PIQ & WD & PP & SP & CS & CSat \\
\hline Product information quality & $\mathbf{0 . 6 6 6}$ & & & & & \\
Website deign & 0.396 & $\mathbf{0 . 6 5 7}$ & & & & \\
Purchasing process convenience & 0.410 & 0.555 & $\mathbf{0 . 7 5 0}$ & & & \\
Security perception & 0.183 & 0.206 & 0.295 & $\mathbf{0 . 7 6 7}$ & & \\
Customer service & 0.334 & 0.289 & 0.367 & 0.211 & $\mathbf{0 . 6 5 4}$ & \\
Customer satisfaction & 0.343 & 0.373 & 0.349 & 0.271 & 0.520 & $\mathbf{0 . 7 4 6}$ \\
\hline
\end{tabular}

\subsection{Hypothesis Testing}

Multiple regression analysis was performed to examine the effect of five constructs on online customer satisfaction and thereby test the five hypotheses. This method is considered as an appropriate method when the research problem includes a single dependent variable which is related with two or more independent variables (Hair et al., 2014). The results of this analysis are presented in Table 6 and Table 7.

Table 5. Model Summary

\begin{tabular}{ccccc}
\hline Model & $\mathrm{R}$ & R Squared & $\begin{array}{c}\text { Adjusted } \\
\text { R Squared }\end{array}$ & Std. Error of the Estimate \\
\hline 1 & $.786^{\mathrm{a}}$ & .618 & .605 & .48874 \\
\hline
\end{tabular}

a. Predictors: (Constant), Customer service, Security Perception, Website Design, Product Information Quality, Purchasing process convenience

b. Dependent Variable: Customer satisfaction

Table 6. Regression results

\begin{tabular}{|c|c|c|c|c|c|c|}
\hline & \multicolumn{2}{|c|}{ Unstandardized Coefficients } & \multirow{2}{*}{$\begin{array}{c}\text { Standardized Coefficients } \\
\text { Beta }\end{array}$} & \multirow[t]{2}{*}{$\mathrm{t}$} & \multirow[t]{2}{*}{ Sig. } & \multirow[t]{2}{*}{ Hypothesis result } \\
\hline & $\mathrm{B}$ & Std. Error & & & & \\
\hline (Constant) & 0.194 & 0.233 & & 0.831 & 0.408 & \\
\hline Product information quality & 0.122 & 0.076 & 0.116 & 1.591 & 0.114 & $\mathrm{H}_{1}$ :Not supported \\
\hline Website deign & 0.239 & 0.084 & 0.232 & 2.861 & 0.005 & $\mathrm{H}_{2}:$ Supported \\
\hline Security perception & 0.157 & 0.059 & 0.168 & 2.675 & 0.008 & $\mathrm{H}_{3}:$ Supported \\
\hline Purchasing process convenience & -0.034 & 0.087 & -0.034 & 0.389 & 0.698 & $\mathrm{H}_{4}$ : Not supported \\
\hline Customer service & 0.472 & 0.069 & 0.473 & 6.832 & 0.000 & $\mathrm{H}_{5}:$ Supported \\
\hline
\end{tabular}

Dependent Variable: Customer satisfaction.

Table 6 indicates the adjusted $\mathrm{R}$ squared (Coefficient of Determination) of the research model. The analysis reported adjusted $\mathrm{R}$ squared value of 0.605 which describes $60.5 \%$ of the variation of the dependent variable (Online customer satisfaction) is explained by the five independent variables (product information quality, website design, purchasing process convenience, security perception and customer service) used in this study.

As shown in Table 7, regression coefficients for Website design, Security perception and Customer service are positive and significant $(\mathrm{p}<0.05)$. This indicates that each of these three variables has a positive and significant effect on online customer satisfaction. Therefore, hypotheses H2, H4 and H5 are accepted. However, it is apparent that Product information quality and Purchasing process convenience have no significant effect on 
online customer satisfaction. Consequently, hypotheses $\mathrm{H} 1$ and $\mathrm{H} 3$ are rejected.

Besides that, multiple regression results (Table 7) show that customer service has the highest impact $(\beta=0.473$ ) on online customer satisfaction, followed by website design $(\beta=0.232)$ and security perception $(\beta=0.168)$. This illustrates that customer service is the most important construct influencing the online customer satisfaction amongst the constructs considered in this study. Finally, both Product information quality and Purchasing process convenience have less practical significance to the assessment of online customer satisfaction.

\section{Discussion}

In this study authors examined five literature based online customer satisfaction determinants in order to identify their effect on customer satisfaction in online shopping context. Findings of the study are consistent with previous findings to a greater extent.

Results of the study revealed that online customer satisfaction is positively and significantly influenced by customer service. This finding is consistent with the previous findings of Ranjbarian et al. (2012); Liu et al. (2008); Zeng et al. (2009); and Trong et al. (2014). According to the findings, there is a significant relationship between website design and online customer satisfaction. Similar results have been reported by Szymanski and Hise (2000); Cho and Park (2001); Part and Kim (2003); Liu et al (2010); Maditinos and Theordoridis (2010); Ting et al. (2016). Therefore, it is apparent that the findings of this study is consistent with previous findings.

Results of the study indicate that there is a positive and significant relationship between security perception and online customer satisfaction. These findings are consistent with the previous findings of Szymanski \& Hise (2000); Park and Kim (2003); Eid (2011); Ranjbarian et al. (2012); and Evanschitzky et al. (2014). In addition, results concluded that other two variables used in this study (product information quality and purchasing process convenience) do not have significant effect on online customer satisfaction. Thus, results revealed that there is no significant relationship between product information quality and customer satisfaction. This finding is consistent with the previous findings of Evanschitzky et al., (2004). They have also revealed that there is no significant association between product information and e-satisfaction. Further, authors found that the relationship between purchasing process convenience and online customer satisfaction is not significant. However, it is apparent that this finding is not inconsistent with the previous studies done by Liu et al. (2008) and Trong et al. (2014).

This study has both theoretical and practical implications. Consequently, the study has implications for researchers, academics and online retailers.

\subsection{Theoretical Implications}

This study contributes to the theory by presenting a theoretical framework which supports to determine antecedents of online customer satisfaction and the effect of each variable on customer satisfaction. The significant relationships found in the study strengthen the existing knowledge related to online customer satisfaction. The findings may be more relevant to a developing country perspective where there is lesser number of online transactions performed by customers compared to developed countries. The findings help us to further our understanding in relation to the under-researched area of online customer satisfaction, especially in the Sri Lankan context. The study also contributed by validating five constructs (Website design, Security perspective, Customer service, Product information quality and Purchasing process convenience) used in this study, which were derived from previous conceptual frameworks studied in the literature. Finally, this study can induce future research because of the growing importance of online transactions, especially in developing nations.

\subsection{Practical Implications}

Also, the study will provide insights for managers, as well as for online retailers in several aspects. Due to high competition existing in the online context, businesses need to pay greater attention on customer satisfaction to attract and retain customers. The study helps the online retailer to identify the specific factors leading to the satisfaction of online customers. Further, they can identify the specific indicators of each factor, enabling them to focus on those areas to achieve greater customer satisfaction. This may even increase the preference of customers for online transactions, which is vital from online retailers' perspective. Thus, as found in this study, online retailers need to focus on Website design, Security perspective, and Customer service to increase customer satisfaction, helping them to retain those customers with them in the long run.

According to this study, customer service is the most critical factor that should be addressed by online retailers. Firstly, readiness and willingness of customer support staff of the retailer to address customer issues and provide prompt responses will be important to satisfy the customers. Lack of adequate customer support and delays in responses will result in dissatisfaction among customers. Secondly, the availability of multiple channels to contact can result in increased satisfaction since different customers usually prefer different contact options. 
Finally, availability of tracking of delivery has also been identified as an important area to be addressed by the online retailers. Thus, the online retailers need to pay proper attention to those areas and address them appropriately to increase customer satisfaction, which in turn will lead to increased sales.

The study suggests that online retailer need to pay a greater attention for website design. Firstly, there is a necessity to focus on the convenience of the usage of the website. When users find that a website is not user friendly and not convenient to use, they tend to leave it quickly. Secondly, it is necessary to build websites that are attractive and have good layout. Consequently, the colour combinations used, how the content is presented and arranged in the website matter a lot for the online retailer to attract customers and induce them for transactions. Finally, the website should provide a simple and easy method of completing transactions.

Security perspective is another important area that should be addressed by online retailers to increase customer satisfaction. The study provides evidence to the fact that customers are concerned about protecting their personal information. Therefore, the online store should have adequate security features to protect privacy of customers. The retailer may use detailed privacy statements to convince the customer about security and protection of privacy. Further, there is a necessity to build customer trust towards the website. Availability of contact information, reviews of satisfied customers, certification from trusted third parties etc. all can help to develop trust among customers, leading to increased satisfaction and better sales for the retailer.

\section{Conclusion}

The objective of this study was to identify the determinants of online customer satisfaction. In order to achieve this objective, first, a comprehensive literature review was performed. A total of sixty research papers were reviewed during this process. Research papers were carefully selected to ensure the validity and reliability of them. The researchers focused on the research papers which were published in well recognized scientific journals. Amongst the research papers studied, thirty one research papers were related to the determinants of online customer satisfaction. Thus, the thirty one research papers were used in the process of identifying the determinants used in different studies.

This process helped the researchers to explore forty five determinants with different frequencies of usage. After evaluating the forty five determinants, most commonly cited five determinants, with the highest frequencies were selected to develop the conceptual model. Those five determinants included: Website design, Security perception, Customer service, Product Information Quality, and Purchasing Process Convenience. The conceptual model was developed depicting the relationship between each of the determinant identified and online customer satisfaction. Based on the conceptual model, the researchers suggested five hypotheses for this study.

Data were analyzed using Statistical package for social sciences (SPSS) and multiple regression analysis was used to test the hypotheses developed. Analysis revealed that Customer service, Website design, and Security perspective have significant effects on online customer satisfaction. Consequently, three hypotheses were accepted and the balance two hypotheses were rejected. Amongst the factors, Customer service was identified as the most important factor followed by website design and Security perspective.

\section{Limitations and Future Research Directions}

Even though the researchers identified forty-five factors affecting customer satisfaction, the conceptual model was developed using only five factors. Therefore, there are other factors affecting customer satisfaction, which were not examined in this study. Future research can focus on incorporating more factors, leading to better prediction of online customer satisfaction.

The researchers focused only on the direct relationships between identified factors and online customer satisfaction. However, there can be mediating and moderating effects on these relationships. Therefore, future research can focus on such mediating and moderating effects.

This study did not focus on a specific category of product and also no control was used to distinguish between tangible and intangible products. Since the effects of identified factors can change on the type of product purchased, future research can address this issue as well.

\section{References}

Al-Kasasbeh, M., Dasgupta, S., \& Al-Faouri, A. (2011). Factors affecting e-service satisfaction. Communications of the IBIMA, 1-12.

Alam, S. S., \& Yasin, N. M. (2010). An investigation into the antecedents of customer satisfaction of online shopping. Journal of Marketing Development and Competitiveness, 5(1), 71-79. 
Anand, A. (2007). E-satisfaction - A comprehensive framework. Second International Conference on Internet and Web Applications and Services.

Bellaaj, M. (2013). Web-based information systems success: testing the antecedents of online customer satisfaction. International Journal of Internet and Enterprise Management, 8(2), 129-145. https://doi.org/10.1504/IJIEM.2013.055959

Bhattacherjee, A. (2001). An empirical analysis of the antecedents of electronic commerce service continuance. Decision Support Systems, 32(2), 201-214. https://doi.org/10.1016/S0167-9236(01)00111-7

Bougie, R., Pieters, R., \& Zeelenberg, M. (2003). Angry customers don't come back, they get back: the experience and behavioral implications of anger and dissatisfaction in services. Journal of the Academy of Marketing Science, 31(4), 377-393. https://doi.org/10.1177/0092070303254412

Casalo, L., Flavian, C., \& Guinaliu, M. (2008). The role of usability and satisfaction in the consumer's commitment to a financial services website. International Journal of Electronic Finance, 2(1), 31-49. https://doi.org/10.1504/ijef.2008.016883

Chang, H. H., \& Chen, S. W. (2009). Consumer perception of interface quality, security, and loyalty in electronic commerce. Information and Management, 46(7), 411-417. https://doi.org/10.1016/j.im.2009.08.002

Chen, Z., Ling, K. C., Ying, G. X., \& Meng, T. C. (2012). Antecedents of online customer satisfaction in China. International Business Management, 6(2), 168-175. https://doi.org/10.3923/ibm.2012.168.175

Cho, N., \& Park, S. (2001). Development of electronic commerce user- consumer satisfaction index for internet shopping. Industrial Management and Data Systems, 101(8), 401-405, https://doi.org/10.1108/EUM0000000006170

Churchill, G. A., \& Surprenant, C. (1982). An investigation in to determinants of customer satisfaction. Journal of Marketing Research, 19(4), 491-504. https://doi.org/10.2307/3151722

Dharmesti, M. D. D., \& Nugroho, S. S. (2012). The Antecedents of online customer satisfaction and customer loyalty. The Business \&Management Review, 7(2), 57-68.

Evanschitzky, H., Iyer, G. R, Hesse, J., \& Ahlert, D. (2004). E-satisfaction: A re-examination. Journal of Retailing, 80(3), 239-247. https://doi.org/10.1016/j.jretai.2004.08.002

Flavián, C., Guinalíu, M., \& Gurrea, R. (2006). The role played by perceived usability, satisfaction and consumer trust on website loyalty. Information and Management, 43(1), 1-14. https://doi.org/10.1016/j.im.2005.01.002

Gelard, P., \& Negahdari, A. (2011). A new framework for customer satisfaction in electronic commerce. Australian Journal of Basic and Applied Sciences, 5(11), 1952-1961.

George, D., \& Mallery, P. (2016). IBM SPSS Statistics 23 step by step: a simple guide and reference (14th ed.). New York, NY: Routledge,

Giese, J. L., \& Cote, J. A. (2000). Defining Consumer Satisfaction. Academy of Marketing Science Review, (1), $1-27$.

Guo, X., Ling, K. C., \& Liu, M. (2012). Evaluating factors influencing consumer satisfaction towards online shopping in China. Asian Social Science, 8(13), 40-49. https://doi.org/https://doi.org/10.5539/ass.v8n13p40

Hair, J., F., Black, W. C., Babin, B. J., \& Anderson, R. E. (2014). Multivariate Data Analysis (7th ed.). England, Pearson Education.

Harn, A. C. P., Khatibi, A., \& Ismail, H. B. (2006). E-commerce: A study on online shopping in Malaysia. Journal of Social Sciences, 13(3), 231-242. https://doi.org/10.1080/09718923.2006.11892554

Jiang, P., \& Rosenbloom, B. (2005). Customer intention to return online: price perception, attribute-level performance and satisfaction unfolding over time. European Journal of Marketing, 39(01/02), 150-174. https://doi.org/10.1108/03090560510572061

Khan, S. A., Liang, Y., \& Shahzad, S. (2015). An empirical study of perceived factors affecting customer satisfaction to repurchase intention in online store in China. Journal of Service Science and Management, 8(3), 291-305. https://doi.org/10.4236/jssm.2015.83032

Kim, H. R. (2005). Developing an index of online customer satisfaction. Journal of Financial Services Marketing, 10(01), 49-64. https://doi.org/10.1057/palgrave.fsm.4770173 
Kim, J., Jin, B., \& Swinney, J. L. (2009). The role of etail quality, e-satisfaction and e-trust in online loyalty development process. Journal of Retailing and Consumer Services, 16(4), 239-247. https://doi.org/10.1016/j.jretconser.2008.11.019

Kim, S., \& Stoel, L. (2004). Apparel retailers: Website quality dimensions and satisfaction. Journal of Retailing and Consumer Services, 11(2), 109-117. https://doi.org/10.1016/S0969-6989(03)00010-9

Kotler, P., \& Keller, K. L. (2012). Marketing Management (15th ed.). New Jersy, Prentice Hall.

Lee, G., \& Lin, H. (2005).). Customer perceptions of e-service quality in online shopping. International Journal of Retail \& Distribution Management, 33(2), 161-176. https://doi.org/10.1108/09590550510581485

Lin, C. C., Wu, H. Y., \& Chang, Y. F. (2011). The critical factors impact on online customer satisfaction. Procedia Computer Science, 3(2011), 276-281. https://doi.org/10.1016/j.procs.2010.12.047

Lin, H. F. (2007). The impact of website quality dimensions on customer satisfaction in the B2C e-commerce context. Total Quality Management and Business Excellence, 18(4), 363-378. https://doi.org/10.1080/14783360701231302

Liu, X., He, M., Gao, F., \& Xie, P. (2008). An empirical study of online shopping customer satisfaction in China: A holistic perspective. International Journal of Retail and Distribution Management, 36(11), 919-940. https://doi.org/10.1108/09590550810911683

Maditinos, D. I., \& Theodoridis, K. (2010). Satisfaction determinants in the Greek online shopping context. Information Technology and People, 23(4), 312-329. https://doi.org/10.1108/09593841011087789

McKnight, D. H., Choudhury, V., \& Kacmar, C. (2002). The impact of initial consumer trust on intentions to transact with a web site: a trust building model. Journal of Strategic Information Systems, 11(2002), 297-323. https://doi.org/10.1016/S0963-8687(02)00020-3

Momtaz. H., Islam, A. M., Ariffin, K .H. K., \& Karim, A. (2011). Customer satisfaction on online shopping in Malaysia. International Journal of Business and Management, 6(11), 162-169. https://doi.org/10.5539/ijbm.v6n10p162

Moriuchi, E., \& Takahashi, I. (2016). Satisfaction trust and loyalty of repeat online consumer within the Japanese online supermarket trade. Australasian Marketing Journal, 24(2), 146-156. https://doi.org/10.1016/j.ausmj.2016.02.006

Oliver, R. L. (2015). Satisfaction: A Behavioral Perspective on the Consumer. New York, NY: Routledge.

Pappas, I. O., Pateli, A. G., Giannakos, M. N., \& Chrissikopoulos, V. (2014). Moderating effects of online shopping experience on customer satisfaction and repurchase intentions. International Journal of Retail and Distribution Management, 42(3), 187-204. https://doi.org/10.1108/IJRDM-03-2012-0034

Park, C. H., \& Kim, Y. G. (2003). Identifying key factors affecting consumer purchase behavior in an online shopping context. International Journal of Retail \& Distribution Management, 31(1), 16-29. https://doi.org/10.1108/09590550310457818

Polites, G. L., Williams C. K., Karahanna, E., \& Seligman, L. (2012). A theoretical framework for consumer e-satisfaction and site stickiness: an evaluation in the context of online hotel reservations. Journal of Organizational Computing and Electronic Commerce, 22(1), 1-37. https://doi.org/10.1080/10919392.2012.642242

Ranjbarian, B., Fathi, S., \& Rezaei, Z. (2012), Factors influencing on customers' E-satisfaction: a case study from Iran. Interdisciplinary Journal of Contemporary Research in Business, 3(9), 1496-1511.

Saunders, M., Lewis, P., \& Thornhill, A. (2009). Research methods for Business students (5th ed.). England, Pearson Education.

Schaupp, L. C., \& Bélanger, F. (2005). A conjoint Analysis of Online Consumer Satisfaction. Journal of Electronic Commerce Research, 6(2), 95-111.

Silva, L. A. R. H. D., \& Abeysekara, N. (2012). Influence of Internet banking on customer satisfaction in the Sri Lankan context. Annual Academic Sessions, Open University of Sri Lanka, pp.183-185.

Swan, J. E., \& Combs, L. J. (1976). Product Performance and Consumer Satisfaction: A New Concept. Journal of Marketing, 40(2). 25-33. http://psycnet.apa.org/doi/10.2307/1251003

Szymanski, D. M., \& Hise, R. T. (2000). E- satisfaction: An initial examination. Journal of Retailing, 76(3), 309-322. https://doi.org/10.1016/S0022-4359(00)00035-X 
Tandon, U., Kiran, R., \& Sah, A. (2017). Analyzing customer satisfaction: users perspective towards online shopping. Nankai Business Review International, 8(3), 266-288. https://doi.org/10.1108/NBRI-04-2016-0012

Thilakarathne, C., \& Abeysekara, N. (2016). Influencing factors for customer satisfaction of mobile-money services, with special reference to mcash service by mobitel Sri Lanka. Asia Pacifit Journal of Marketing and Retail Management, 7(2), 2317-2349.

Ting, O. S., Ariff, M. S. M., Zakuan, N., Sulaiman, Z., \& Saman, M. Z. M. (2016). E-Service Quality, E-Satisfaction and E-Loyalty of Online Shoppers in Business to Consumer Market; Evidence form Malaysia. IOP Conference Series: Materials Science and Engineering, 131, 1-11.

Trong, V. H., Khanh N. T. V., \& Gim, G. (2014). Evaluating factors influencing consumer satisfaction towards online shopping in Viet Nam. Journal of Emerging Trends in Computing and Information Sciences, 5(1), 67-71. https://doi.org/10.5539/ass.v8n13p40

Walczuch, R., \& Lundgren, H. (2004). Psychological antecedents of institution-based consumer trust in e-retailing. Information and management, 42, 159-177. https://doi.org/10.1016/j.im.2003.12.009

Wang, Y. S., Tang, T. I., \& Tang, J. E. (2001). An instrument for measuring customer satisfaction toward Web sites that market digital products and services. Journal of Electronic commerce research, 2(3), 89-102.

Williams, P., \& Naumann, E. (2011). Customer satisfaction and business performance: a firm-level analysis. Journal of Services Marketing, 25(1), 20-32. https://doi.org/10.1108/08876041111107032

Yang, H., \& Tsai, F. S. (2007). General E-S-QUAL scales applied to websites satisfaction and loyalty model. Communications of the IIMA, 7(2), 115-126.

Yoo, B., \& Donthu, N. (2001). Developing a scale to measure the perceived quality of an internet shopping site (SITEQUAL). Quarterly Journal of Electronic Commerce, 2(1), 31-47. https://doi.org/10.1007/978-3-319-11885-7_129

Zeng, F., Hu, Z., Chen, R., \& Yang, Z. (2009). Determinants of online service satisfaction and their impacts on behavioural intentions. Total Quality Management and Business Excellence, 20(9), 953-969. https://doi.org/10.1080/14783360903181719

\section{Appendix}

\section{Questionnaire}

This questionnaire has been developed to collect data for a research we are pursuing. The main objective of this research is to determine the factors affecting satisfaction of online customers. Please read all the statements given below carefully and give your true opinion as it is vital for the success of our research study. All the information collected through this survey will be used only for the purpose of this research. Therefore, we assure you that the information provided by you will be treated with the utmost confidence.

\section{Section I - Respondent Profile (Basic information)}

\section{Please tick $(\sqrt{ })$ the most appropriate number.}

\section{Gender}
Male
Female

2. Age

$18-30 \quad \square 1-45$

Above 45

\section{Highest Educational Qualification}

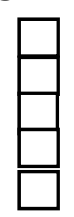

Diploma

Professional Qualification (CA, CIMA, ACCA, CMA, CIM, SLIM etc.)

Undergraduate Degree

Postgraduate degree

Any other (Please specify: 
4. Monthly Income

$\square$ Less than Rs.50, $000 \square$ Rs.50,000 - Rs.100,000 $\square$ More than Rs. 100,000

5. Have you ever had online shopping?

$\square$ Yes $\square$ No

6. Frequency of online shopping experience during the last year

\begin{tabular}{ll}
$\square$ & Never \\
\hline$\square$ Less than 5 times & $\square-20$ times \\
\hline More than 20 times
\end{tabular}

If the answer to above question number 5 is "Yes", please move to Section II.

If the answer to above question number 5 is "No", please do not attempt Section II.

Section II - (Online shopping related opinion)

Please evaluate your opinion regarding each of the following statement in the scale from "Strongly Disagree" to "Strongly Agree" by placing a tick $(\sqrt{ })$ in the most appropriate cage, based on your last online shopping experience.

The scale to be used in providing the responses is as follows.

1 - Strongly disagree $\quad 2$-Disagree $\quad 3$-Neutral $\quad 4$-Agree $\quad 5$-Strongly agree

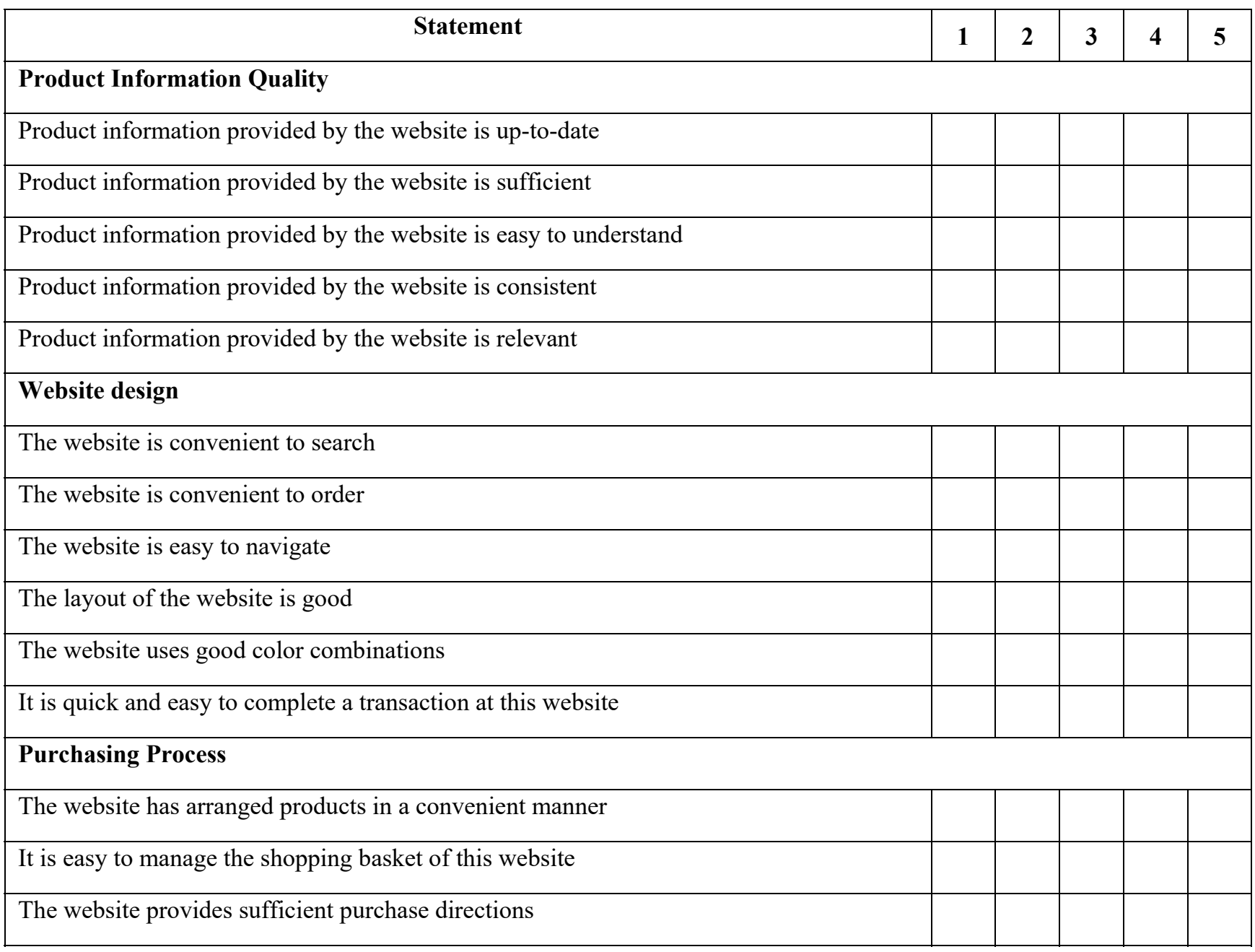




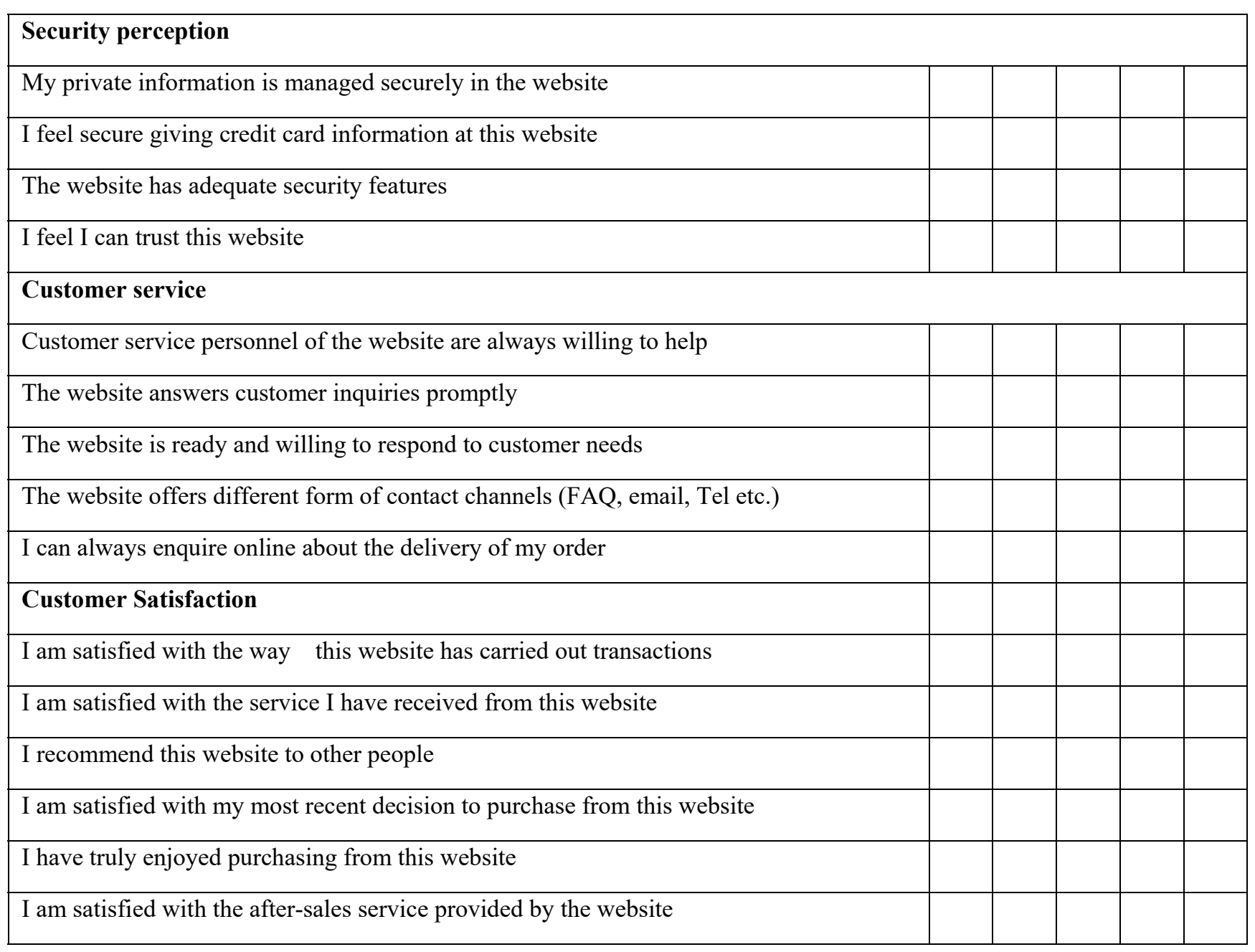

\section{Copyrights}

Copyright for this article is retained by the author(s), with first publication rights granted to the journal.

This is an open-access article distributed under the terms and conditions of the Creative Commons Attribution license (http://creativecommons.org/licenses/by/4.0/). 